\title{
Tumor Necrosis Factor-a Induced Cellular Stress on Trophoblastic Cells: NF-kB Signaling Could be a Potential Therapeutic Target
}

\author{
Erengul Tokay Varolli' ${ }^{\oplus}$, Serbay Ozkan' ${ }^{\circledR}$, Burcu Biltekin ${ }^{1} \odot$, Meral Koyuturk ${ }^{1}$ \\ IIstanbul University-Cerrahpasa, Cerrahpasa Medical Faculty, Histology and Embryology Department, Turkey
}

ORCID IDs of the authors: E.T.V. 0000-0002-0270-5069; S.0. 0000-0001-7854-4735; B.B. 0000-0002-8435-6797;

M.K. 0000-0002-0270-5069

Please cite this article as: Tokay Varolli E, Ozkan S, Biltekin B, Koyuturk M. Tumor Necrosis Factor-a Induced Cellular Stress on Trophoblastic Cells: NF-kB Signaling Could be a Potential Therapeutic Target. Eur J Biol 2021; 80(1): 9-14. DOI: 10.26650/EurJBiol.2021.800412

\begin{abstract}
Objective: The development of the human placenta depends on proliferation and differentiation of trophoblastic cells. Deficiencies in trophoblastic functions are known to have a critical role in the progression of placental pathologies such as preeclampsia. Therefore, in this research, it was aimed to evaluate the responses of trophoblastic cells to tumor necrosis factor-a (TNF-a) mediated cellular stress.
\end{abstract}

Materials and Methods: In this study, the cellular stress model was set up by treating JAR cells with 100ng/ml TNF-a for 1 , 6,12 and 24 hour long periods. In this model, the effects of TNF-a on the proliferation capacity and apoptotic activity of JAR trophoblastic cells were investigated by immunocytochemistry. The nuclear and total expression levels of nuclear factor- $\mathrm{KB}$ (NF-KB) was evaluated with immunocytochemistry and Western blot, respectively.

Results: It was shown that $100 \mathrm{ng} / \mathrm{mlTNF}-\mathrm{a}$ treated cells had a reduced proliferative capacity and increased apoptotic activity by immunocytochemical staining of PCNA and caspase-8 proteins respectively. In this respect, the NF-KB signaling pathway plays a critical role in TNF- $a$ induced processes. So that, it was shown that the TNF- $a$ treated group had increased nuclear and total NF-KB expressions compared to the untreated one.

Conclusion: Our findings showed that TNF-a has a significant role as a cellular stress source in JAR cells. TNF-a stimulated cellular response could be defined as decreased proliferative capacity, increased apoptotic activity and NF-KB signaling in JAR syncytiotrohoblastic cell lines. Therefore, investigation of TNF-a related cellular responses especially NF-KB signaling is further required for the understanding of the mechanism of placental pathologies which is crucial for the development of therapeutic approaches.

Keywords: Cellular stress, NF-kB signaling pathway, placenta, TNF- $a$, trophoblastic cells

\section{INTRODUCTION}

The development of the human placenta depends on the proliferation and differentiation of trophoblastic cells. In this respect, dysfunction of trophoblasts plays an important role in the development of placental pathologies (1). Therefore, an aberrant development and differentiation of the villous syncytiotrophoblast risks the integrity of the placental barrier and causes the release of necrotic and aponecrotic trophoblast frag- ments (2). Histological evidences suggest a role for trophoblasts in remodeling of the uterine spiral arteries. The disruption of trophoblastic invasion and incomplete remodeling result in reduction of uteroplacental perfusion, which in turn could cause ischemia of the placenta. The alterations resulted from ischemic placenta lead to increased production of oxidative stress and stimulation of proinflammatory cytokine secretion. In this connection, it was found that production of proinflammatory cytokines such as tumor necrosis fac- 
tor alpha (TNF-a) was increased in placental pathologies including preeclampsia $(3,4)$. TNF-a regulates the expression of genes associated with inflammation, cell survival, proliferation and differentiation mainly through the activation of the nuclear factor $\mathrm{KB}(\mathrm{NF}-\mathrm{KB})$ signaling pathway $(5,6)$. TNF- $\mathrm{a}$ is associated with apoptotic cell death via two distinct caspase-8 activation pathways. One of the pathways is regulated by cIAP1 (cellular inhibitor of apoptosis protein 1) and CIAP2, the two of which join to form the signaling complex referred to as complex I that leads to the activation of the NF-KB pathway (7). On the other hand, pentoxifylline (PTX), which is a pharmacologic agent used for improving the circulation, has been reported to have various effects at the cellular level including inhibition of TNF-a $(8,9)$.

TNF-a gene expression was demonstrated at endometrial cells, decidual cells and trophoblastic cells during the trimesters of pregnancy (10). Moreover a group of pregnancy pathologies was associated with increased maternal TNF-a, which was suggested to influence fetal-maternal crosstalk during pregnancy. In this respect, because it is difficult to elucidate the role of TNF-a in such a complex process in in vivo, in vitro experiments with cell lines treated with recombinant TNF-a could be illuminating. Therefore, in this research, it was aimed to examine the response of trophoblasts to TNF-a mediated cellular stress in the JAR cell line by the evaluation of proliferative, apoptotic indexes and expression levels of NF-kB which is a key signaling molecule and to assess the therapeutic potential of PTX in TNF-a induced interactions.

\section{MATERIALS AND METHODS}

\section{Cell Culture}

JAR human choriocarcinoma cell line was purchased from the American Type Culture Collection. The cells were cultured in Dulbecco's modified Eagle's medium/F12 medium with 10\% heat inactivated fetal bovine serum under the humidified atmosphere with $5 \% \mathrm{CO}_{2}$ at $37^{\circ} \mathrm{C}$. First of all, the cells grown on coverslips were cultured with experimental doses of TNF-a (PIRP-10921, Thermo Fisher, MA, USA) ranging from 0.1 to 1000 $\mathrm{ng} / \mathrm{ml}$; the optimal dose of TNF-a was determined in accordance with evaluation of NF-kB expressions preliminarily. Then experimental groups were organized at 1, 6, 12 and 24 h-long $100 \mathrm{ng} / \mathrm{ml}$ TNF-a treatment. Afterwards, experimental groups were set up, treating the cells with 1, 10 and $20 \mathrm{mM}$ doses of PTX (prepared from $100 \mathrm{mg}$ per injection ampule) in the presence of TNF-a or not for $1 \mathrm{~h}$.

\section{Immunocytochemistry}

JAR cells were fixed with cold methanol. Following the incubation with blocking serum at room temperature, primary antibodies against proliferating cell nuclear antigen (PCNA) (MA116827, Thermo Fisher, MA, USA), caspase-8 (PI-MA1-91442, Thermo Fisher, MA, USA) and NF-kB p65 (Sc-109, Santa Cruz, CA, USA) were applied overnight at $4^{\circ} \mathrm{C}$. After washing with phosphate buffered saline (PBS), biotinylated secondary antibodies and horseradish peroxidase (HRP) conjugated streptavidin were applied in order. Finally, after treatment with aminoethyl carba- zole, the cells were investigated with an Olympus BX-61 bright field microscope. Proliferation indexes were calculated by taking the averages of the values obtained by dividing the number of PCNA positive cells by the total number of cells in each one of the 5 different areas. The intensities of immunocytochemical stainings for caspase-8 and NF-KB were semi-quantitatively scored in accordance with the following grading system: 0 (no staining), 1+ (weak, but detectable staining), 2+ (moderate or distinct staining), and $3+$ (intense staining). Experiments were repeated three times and histological scores (HSCORE) were obtained for each slide. HSCORE $=\Sigma \mathrm{Pi}(i+1)$, where i represents the intensity score, and $\mathrm{Pi}$ is the corresponding percentage of the cells (11).

\section{DAPI Staining}

The cells cultured on lamellas were treated with $100 \mathrm{ng} / \mathrm{ml}$ TNF-a for $24 \mathrm{~h}$ and then fixed with $4 \%$ of paraformaldehyde. After two times of washing with phosphate buffered saline (PBS) for 5 min, 4,6-diamidino-2-phenylindole dihydrochloride (DAPI) stain was applied to detect apoptotic cells with their characteristic nucleus morphologies (nuclear compaction, fragmentation or semilunar appearance). The samples were investigated under an Olympus BX-61 florescence microscopy and apoptotic indexes were calculated by dividing the number of apoptotic cells by the total cell number.

\section{Western Blot Analysis}

JAR cells grown in different experimental conditions were washed with ice-cold PBS and scraped from culture flasks and then lysed with the cell lysis buffer containing a protease inhibitor cocktail to extract the total protein. The collected samples were subjected to electrophoresis on SDS-PAGE gels and transferred to nitrocellulose membranes. The membranes were blocked with $5 \%$ non-fat dried milk and then incubated with anti-NF-kB (Sc-109, Santa Cruz, CA, USA) primary antibodies overnight at $4^{\circ} \mathrm{C}$. After washing the membranes with tris-buffered saline containing $0.1 \%$ Tween 20 for $15 \mathrm{~min}$, they were incubated with goat HRP-conjugated anti-rabbit secondary antibody (PI-31460 Thermo Fisher, USA) for $1 \mathrm{~h}$ at room temperature. Then, following a second washing step, the membranes were also incubated with HRP-conjugated $\beta$-actin primary antibody (Sc-47778, Santa Cruz, CA, USA) as a loading control. The protein bands were visualized by using 3,3'-diaminobenzidine. Experiments were repeated three times and band intensities were quantified by densitometric analysis (Adobe Photoshop CS5) and normalized to $\beta$-actin readings.

\section{Statistical Analyses}

Statistical analyses were performed with Sigma Plot 12.0 software packages for the immunocytochemical and Western blot analyses. The data were presented as mean \pm standard error (SE). Analysis between the groups were performed with One Way ANOVA test followed by Student t-test and non-parametric Kruskal Wallis-H tests for the immunocytochemistry and Western blot scores respectively. $A$ value of $p<0.05$ was considered statistically significant. 


\section{RESULTS}

In accordance with our preliminary studies, $100 \mathrm{ng} / \mathrm{ml}$ TNF-a was determined as an optimal dose for cellular stress induction in JAR cells. In this respect, the effects of cellular stress over the proliferation capacity of JAR cells were evaluated at the end of the 6,12 and $24 \mathrm{~h}$ long incubations with TNF-a through the

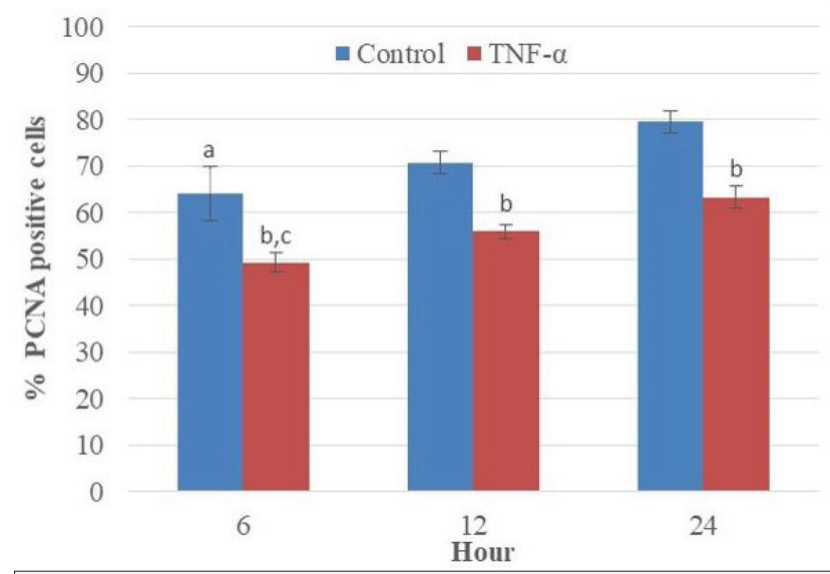

Figure 1. Proliferation indexes expressed with percentages (\%) of PCNA positive cells for the control and TNF-a treated cell groups with different time intervals. ${ }^{a} P<0.05$ vs 12 - and 24 -hour control groups. ${ }^{b} P<0.05$ vs control groups. ${ }^{c} P<0.05$ vs 12 - and $24-$ hour of TNF-a treated cell groups.
PCNA immunocytochemical analysis. The percentages of PCNA expressing cells after TNF-a treatment were statistically lower than the control and PCNA expression tended to increase with higher incubation time from $6^{\text {th }}$ hr (Figure 1).

Second of all, cellular stress related apoptotic activity in JAR cells was investigated by evaluation of the immune reactivity of caspase- 8 at the end of the 1, 6, 12 and $24 \mathrm{~h}$ of treatment with TNF-a. The caspase- 8 immune reactivities of all the TNF- $a$ applied groups were significantly higher than the control group and $1 \mathrm{~h}$ ofTNF-a treatment brought about the highest caspase- 8 immune reactivity (Figure $2 \mathrm{~A}$ ). Furthermore, cells treated with TNF-a for $24 \mathrm{~h}$ were compared with the non-treated ones by DAPI staining which is specific for DNA in order to show apoptosis related morphologic changes (Figure 2B-D). The number of cells having characteristic apoptotic nuclear morphology in the TNF-a treated group was significantly higher than the ones in the control (Figure 2B).

NF-KB signaling is one of the key pathways for the regulation of expressions of genes related to cell survival and proliferation, and activated by TNF- $a(5,6)$. Therefore, nuclear NF-kB expression levels of the JAR cells were evaluated at the end of the 1-, 6-, 12- and $24 \mathrm{~h}$ long incubation with TNF-a through the immunocytochemical (Figure $3 \mathrm{~A}-\mathrm{E}$ and Table 1) and Western blot analysis (Figure 3F). It was found that $1 \mathrm{~h}$ long induction with TNF-a was effective to induce NF-kB expression significantly (Table 1). At this point, we assessed the effects of dif-
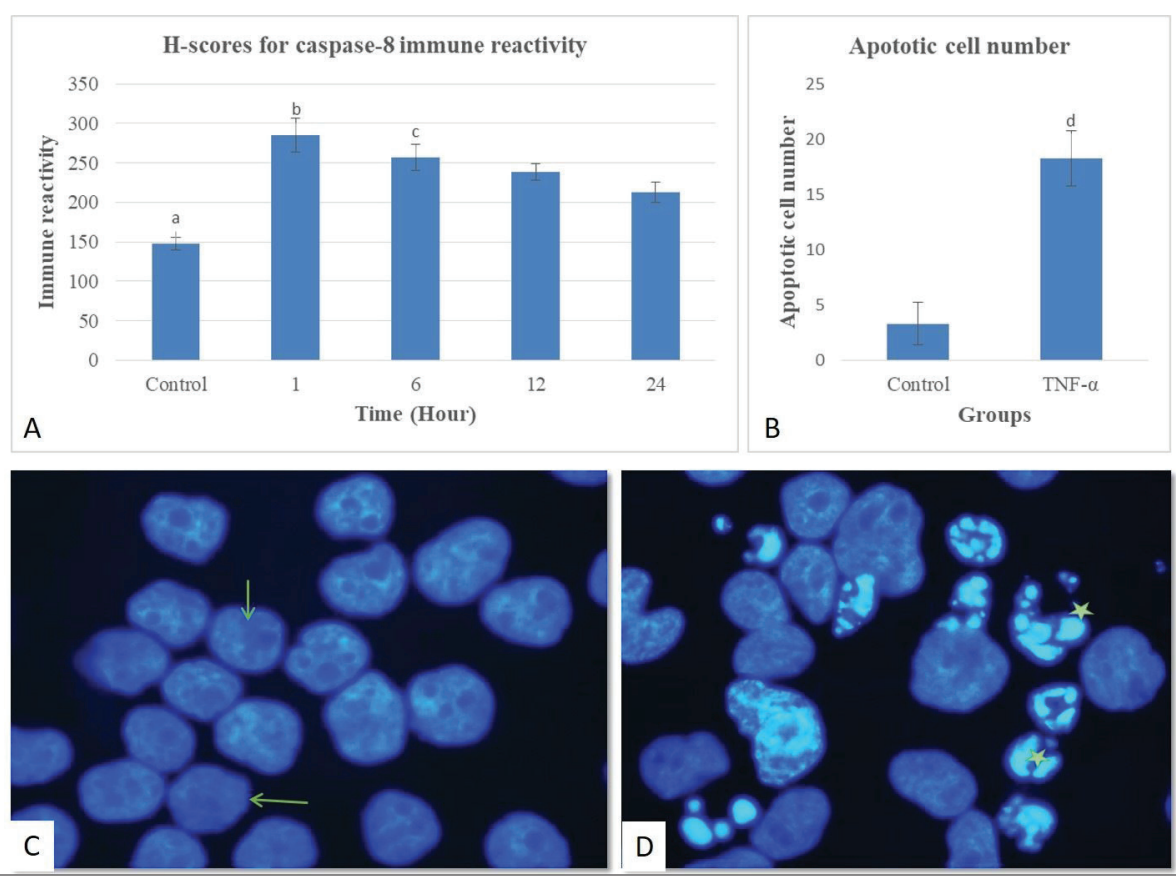

Figure 2. Caspase-8 immune reactivities of control and TNF-a treated cell groups with different time intervals (A). Apoptotic cell rates for the control and 24-hour TNF-a treated cell groups (B). Representative photomicrographs of control (C) and 24-hour long TNF-a treated cells (D) (arrow: normal nucleus morphology; star: apoptotic nucleus morphology, $100 \mathrm{X}$ ). ${ }^{\mathrm{a}} P<0.05$ vs TNF-a treated cell groups. ${ }^{b} P<0.05$ vs $6-, 12$ - and 24 -hour of TNF-a treated cell groups. ${ }^{c} P<0.05$ vs 12 - and 24 -hour of TNF-a treated cell groups. d $P<0.05$ vs control group. 


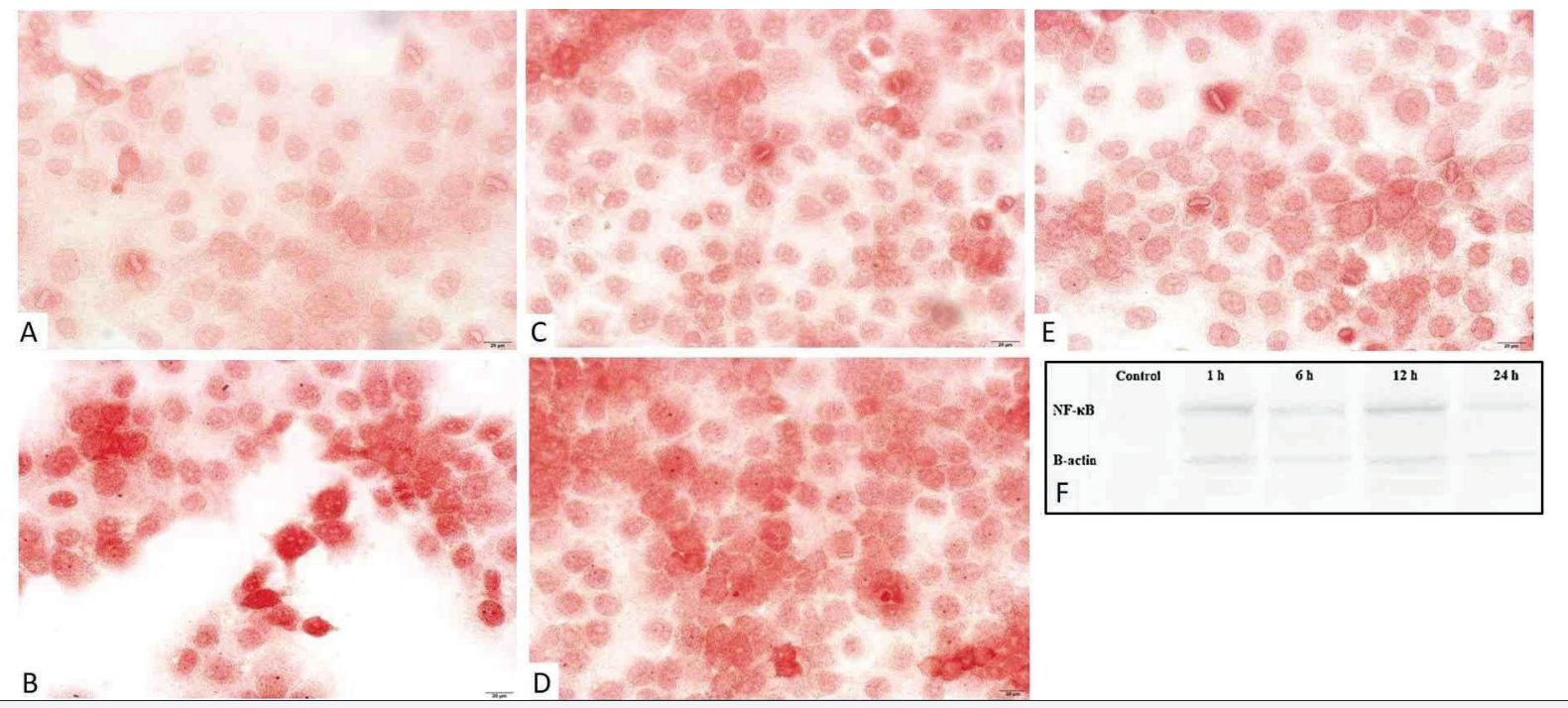

Figure 3. Representative photomicrographs of nuclear NF-KB immune reactivities in control (A), and $1 \mathrm{~h}-(\mathrm{B}), 6 \mathrm{~h}-(\mathrm{C}), 12 \mathrm{~h}-(\mathrm{D})$ and $24 \mathrm{~h}$ long (E) 100ng/ml TNF-a treated groups. Total NF-KB and $\beta$-actin protein levels (F).

Table 1. $\mathrm{H}$ scores for nuclear expressions of NF-KB average \pm SD in the control and TNF-a groups with different time intervals

\begin{tabular}{lc}
\hline Groups & Average \pm SD \\
\hline Ctrl & $169 \pm 7$ \\
\hline TNF- $a(1 h)$ & $329 \pm 7^{\mathrm{ab}}$ \\
\hline TNF- $a(6 h)$ & $219 \pm 9^{\mathrm{a}}$ \\
\hline TNF- $a(12 h)$ & $302 \pm 11^{\mathrm{ab}}$ \\
\hline TNF- $a(24 h)$ & $224 \pm 7^{\mathrm{a}}$ \\
\hline
\end{tabular}

SD: standard deviation, ${ }^{\mathrm{a}} P<0.05$ vs. control (ctrl) group, ${ }^{\mathrm{b}} P<0.05$ vs. $6 \mathrm{~h}$ and $24 \mathrm{~h}$ long TNF-a treated groups.

ferent doses of PTX, which has been reported as an inhibitory molecule for TNF-a on NF-KB expression levels. NF-KB immunoreactivities disappeared in all of the nuclei of cells treated with only $1 \mathrm{mM}, 10 \mathrm{mM}$ and $20 \mathrm{mM}$ PTX. However, it was found that only $10 \mathrm{mM}$ PTX was able to completely abolish the basal level of nuclear NF-KB expression, and significantly reduced

Table 2. $\mathrm{H}$ scores for nuclear expressions of NF-KB average \pm SD in the control, TNF- $\alpha(1 \mathrm{~h})$ and PTX groups.

\begin{tabular}{lc}
\hline Groups & Average \pm SD \\
\hline Ctrl & $169 \pm 7$ \\
\hline TNF- $a(1 \mathrm{~h})$ & $329 \pm 7$ \\
\hline $10 \mathrm{mM}$ PTX & 0 \\
\hline $10 \mathrm{mM}$ PTX + TNF- $a(1 \mathrm{~h})$ & $180 \pm 10^{\mathrm{a}}$ \\
\hline SD: standard deviation, ${ }^{\mathrm{a}} \mathrm{P}<0.05$ vs. TNF- $\mathrm{a}(\mathrm{h} \mathrm{h})$ treated group. \\
\hline
\end{tabular}

the nuclear NF-KB expression induced by 1-h long incubation with $100 \mathrm{ng} / \mathrm{ml}$ TNF-a (Figure 4, Table 2).
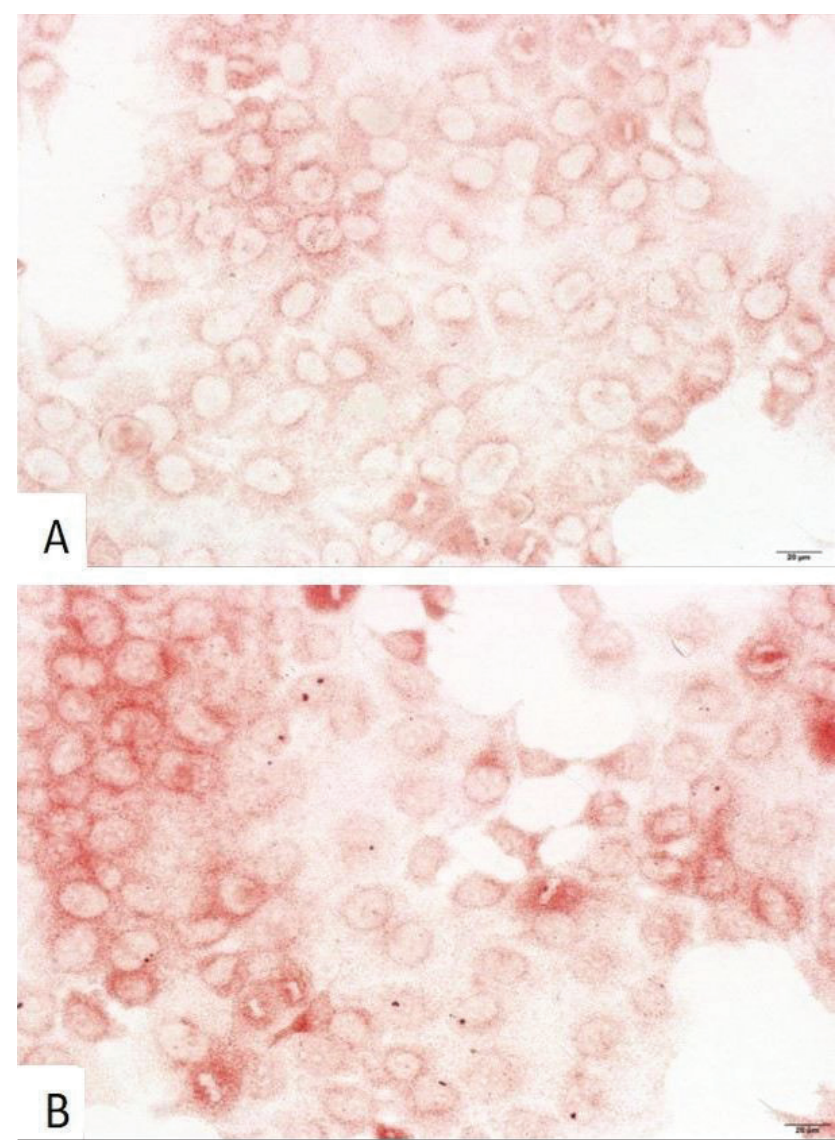

Figure 4. Representative photomicrographs of nuclear NF-KB immune reactivities in $10 \mathrm{mM}$ PTX (A) and $10 \mathrm{mM} \mathrm{PTX} \mathrm{+} \mathrm{TNF-a}$ (B) treated groups. 
Furthermore, Western blot analysis showed that total NF-KB expression was slightly increased with the TNF-a treatment and PTX application reduced total NF-KB expressions significantly compared to the control and only TNF-a treated ones (Figure 5).

\section{NF-KB/ $\beta$-actin}

4,00

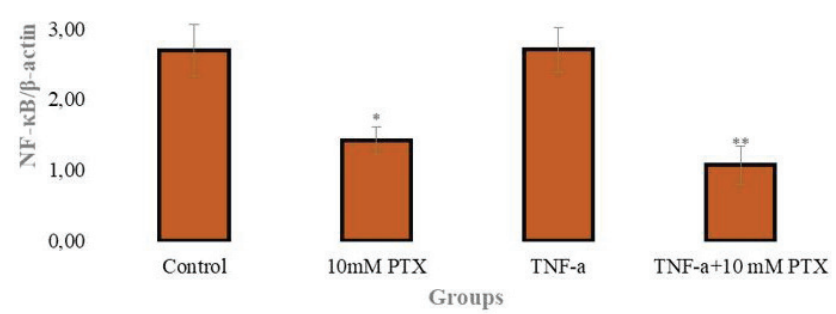

Figure 5. Graphical representation of average densitometric ratios of NF-kB to $\beta$-actin. ${ }^{*} P<0.05$ vs control group, ${ }^{* *} P<0.01$ vs TNF-a group.

\section{DISCUSSION}

Invasiveness of syncytiotrophoblasts is required for remodeling of spiral arteries during pregnancy. Inadequate invasion of trophoblasts leads to a deficient rupture of spiral arteries in the muscular layer, which in turn leads to disruption of utero-placental circulation $(12,13)$. Interrupted arterial blood supply results in an increased generation of inflammatory cytokines like TNF- $a(14,15)$. In this respect, determination of increased level of TNF- $a$ in the plasma of preeclamptic pregnant women has shown that TNF-a could be used as an inducing agent for the establishment of experimental models (16). TNF-a takes part in induction of rapid transcription of genes associated with the regulation of proliferation, cell survival, inflammation and differentiation mainly through activation of the NF-KB pathway (6). For those reasons, it was aimed to evaluate the effects of TNF-a as a potential cellular inducer on JAR trophoblastic cells in our research. First of all, the proliferation indexes of JAR cells were evaluated and it was found that following $6 \mathrm{~h}$ of incubation with TNF-a, proliferating cell numbers was significantly reduced which could be interpreted as TNF-a having an anti-proliferative effect on trophoblastic cells. Caspase- 8 is an initiator caspase, and is predominantly located in mitochondria as a pro-enzyme and released upon apoptotic stimulation like TNF-a (17). Caspase-8 is a prototypic caspase of apoptotic death receptor pathways and activates its ligand by binding to members of the TNF-a receptor superfamily $(18,19)$. In this respect, at the end of the $1 \mathrm{~h}$, cells treated with $100 \mathrm{ng} / \mathrm{ml} \mathrm{TNF-a}$ had significantly higher caspase- 8 immune reactivity. As an initiator caspase, caspase- 8 plays an important role in TNF-a induced cellular stress, which could lead to apoptosis in the end. In this respect, morphologic changes like nuclear fragmentation are a late stage event for apoptosis (20). Therefore, the long-term effects have been showed by DAPI staining at the end of the $24 \mathrm{~h}$ long incubation with TNF-a. Those results support that TNF-a could be one of the main cytokine factors taking part in the placental pathologies, which are associated with trophoblast apoptosis such as preeclampsia. In addition, $100 \mathrm{~nm} / \mathrm{ml}$ TNF-a treatment is quite effective for setting up an in vitro preeclamptic experimental model in trophoblastic JAR cells. Therefore, we wanted to know the role of the NF$K B$ signaling pathway in those processes. In the absence of inducing stimuli, NF-KB molecules are in an inactive state in the cytoplasm. Upon activation by TNF- $a, N F-K B$ is transferred to the nucleus, and regulates the associated genes $(21,22)$. In this respect, the effects of TNF-a treatment on the nuclear NF-kB expression levels in different time intervals were evaluated. In our experiments, we showed that a $1 \mathrm{~h}$ long induction with TNF-a brought about a significant increase in the total and nuclear expression of NF-kB. Even though the nuclear expression of NF-KB was fluctuating with increasing time of TNF- $a$ stimulation, the decrease in proliferative capacity and increase in apoptotic activity are quite consistent with longer incubation time. Similarly, increased NF-KB expression induced with TNF-a was demonstrated in ED27 cells, which are immortalized trophoblast-like cells (23). Furthermore, increased NF-KB expression was also shown for syncytiotrophoblastic cells of preeclamptic placental tissues (24). As a result, we could define a positive feedback loop between TNF- $a$ and NF-KB expressions in JAR trophoblastic cells which possibly participates in progressive aggravation of inflammation in the placenta. PTX, which is a methylxanthine derivative and a non-specific inhibitor of cAMP phosphodiesterase, is generally applied as a pharmacologic agent for improvement of circulation in peripheral vascular disorders $(8,25)$. Moreover, possible therapeutic effects of PTX as an inhibitor of TNF-a synthesis have been investigated in various diseases $(26,27)$. Importantly, it was noted that PTX treatment has a reducing effect on plasma levels of proinflammatory cytokines including TNF in addition to its antioxidant effects (9). In our study, we investigated the optimal dose of PTX for inhibition of TNF-a induced NF-KB expression and it was found that $10 \mathrm{mM}$ PTX application was quite effective in the reduction of TNF-a stimulated nuclear expression of NF-KB. It was reported that NF-KB translocation to nuclei was blocked by PTX application in TNF-a stimulated vascular smooth muscle cells (28). Therefore, PTX could be a potential therapeutic agent for the treatment of TNF-a related placental pathologies.

\section{CONCLUSION}

In summary, the present study showed that incubation with TNF-a leads to a decrease in proliferation capacity and an increase in apoptotic activity and NF-KB signaling in JAR syncytiotrophoblastic cell lines. In addition to all of this, PTX could be a potential regulatory agent for TNF- $a$ induced cellular stress by down regulating the nuclear translocation of NF-KB. Further in vitro and in vivo experiments are required to clarify the effects of PTX which has the potential to be used as a pharmacologic therapeutic in TNF-a associated cellular stress of placental pathologies. 
Peer-review: Externally peer-reviewed.

Conflict of Interest: The authors declare that they have no conflicts of interest to disclose.

Financial Disclosure: This study was funded by the Research Fund of Istanbul University, Project Number: 5737.

Author Contributions: Conception/Design of study: E.T.V., M.K.; Data Acquisition: E.T.V., S.O., B.B.; Data Analysis/Interpretation: E.T.V., S.O., M.K.; Drafting Manuscript: E.T.V., S.O., M.K.; Critical Revision of Manuscript: M.K.; Final Approval and Accountability: M.K.

\section{REFERENCES}

1. Knöfler M, Haider S, Saleh L, Pollheimer J, Gamage TKJB, James J. Human placenta and trophoblast development: key molecular mechanisms and model systems. Cell Mol Life Sci 2019;76:347996.

2. Schoots MH, Gordijn SJ, Scherjon SA, van Goor H, Hillebrands J-L. Oxidative stress in placental pathology. Placenta 2018;69:153-61.

3. Otun HA, Lash GE, Innes BA, Bulmer JN, Naruse K, Hannon T, et al. Effect of tumour necrosis factor-a in combination with interferon- $\gamma$ on first trimester extravillous trophoblast invasion. J Reprod Immunol 2011;88:1-11.

4. Aouache R, Biquard L, Vaiman D, Miralles F. Oxidative stress in preeclampsia and placental diseases. Int J Mol Sci 2018;19:1496.

5. Schütze S, Wiegmann K, Machleidt T, Krönke M. TNF-induced activation of NF-KB. Immunobiology 1995;193:193-203.

6. Hayden MS, Ghosh S. Regulation of NF-KB by TNF family cytokines. Semin Immunol 2014;26:253-66.

7. Wang L, Du F, Wang X. TNF-a induces two distinct caspase-8 activation pathways. Cell 2008;133(4):693-703.

8. McCarty MF, O'Keefe JH, DiNicolantonio JJ. Pentoxifylline for vascular health: a brief review of the literature. Open Hear 2016;3:e000365.

9. Samlaska CP, Winfield EA. Pentoxifylline. J Am Acad Dermatol 1994;30:603-21.

10. Chen HL, Yang Y, Hu XL, Yelavarthi KK, Fishback JL, Hunt JS. Tumor necrosis factor alpha mRNA and protein are present in human placental and uterine cells at early and late stages of gestation. Am J Pathol 1991;139(2):327-35.

11. Guzel E, Basar M, Ocak N, Arici A, Kayisli UA. Bidirectional interaction between unfolded-protein-response key protein HSPA5 and estrogen signaling in human endometrium. Biol Reprod 2011;85:121-7.

12. Cetin I, Huppertz B, Burton G, Cuckle H, Gonen R, Lapaire O, et al. Pregenesys pre-eclampsia markers consensus meeting: What do we require from markers, risk assessment and model systems to tailor preventive strategies? Placenta 2011;32:S4-16.
13. Roberts JM, Gammill HS. Preeclampsia. Hypertension 2005;46:1243-9.

14. Uzun M, Gencer M, Turkon H, Oztopuz RO, Demir U, Ovali MA. Effects of melatonin on blood pressure, oxidative stress and placental expressions of TNFa, IL-6, VEGF and sFIt- 1 in RUPP rat model of preeclampsia. Arch Med Res 2017;48:592-8.

15. Raghupathy R. Cytokines as key players in the pathophysiology of preeclampsia. Med Princ Pract 2013;22:8-19.

16. Weel IC, Baergen RN, Romão-Veiga M, Borges VT, Ribeiro VR, Witkin SS, et al. Association between placental lesions, cytokines and angiogenic factors in pregnant women with preeclampsia. PLoS One 2016;11:e0157584.

17. Qin ZH, Wang Y, Kikly KK, Sapp E, Kegel KB, Aronin N, et al. Procaspase- 8 is predominantly localized in mitochondria and released into cytoplasm upon apoptotic stimulation. J Biol Chem 2001;276(11):8079-86.

18. Boldin MP, Goncharov TM, Goltsev Y V., Wallach D. Involvement of $\mathrm{MACH}$, a novel MORT1/FADD-interacting protease, in Fas/APO-1and TNF receptor-induced cell death. Cell 1996;85:803-15.

19. Muzio M, Chinnaiyan AM, Kischkel FC, O'Rourke K, Shevchenko A, $\mathrm{Ni}$ J, et al. FLICE, a novel FADD-homologous ICE/CED-3-like protease, is recruited to the CD95 (Fas/APO-1) death-inducing signaling complex. Cell 1996;85:817-27.

20. Collins JA, Schandl CA, Young KK, Vesely J, Willingham MC. Major DNA fragmentation is a late event in apoptosis. J Histochem Cytochem 1997;45(7):923-34.

21. Albensi BC. What is nuclear factor kappa $B(N F-k B)$ doing in and to the mitochondrion? Front Cell Dev Biol 2019;7.

22. Durand JK, Baldwin AS. Targeting IKK and NF-KB for therapy. Adv Protein Chem Struct Biol 2017, p. 77-115.

23. Kniss DA, Rovin B, Fertel RH, Zimmerman PD. Blockade NF-KB activation prohibits TNF-a-induced cyclooxygenase-2 gene expression in ED27 trophoblast-like cells. Placenta 2001;22(1):80-9.

24. Armistead B, Kadam L, Drewlo S, Kohan-Ghadr HR. The role of NFKB in healthy and preeclamptic placenta: Trophoblasts in the spotlight. Int J Mol Sci 2020;21(5):1775.

25. Ciuffetti G, Mercuri M, Ott C, Lombardini R, Paltriccia R, Lupattelli G, et al. Use of pentoxifylline as an inhibitor of free radical generation in peripheral vascular disease. Eur J Clin Pharmacol 1991;41:511-5.

26. Hendawy N. Pentoxifylline attenuates cytokine stress and Fas system in syngeneic liver proteins induced experimental autoimmune hepatitis. Biomed Pharmacother 2017;92:316-23.

27. Muchhala SK, Benzeroual KE. Pentoxifylline suppressed LPS-induced inflammatory and apoptotic signaling in neuronal cells. Adv Biosci Biotechnol 2012;03:731-9.

28. Chen YM, Tu CJ, Hung KY, Wu KD, Tsai TJ, Hsieh BS. Inhibition by pentoxifylline of TNF-a-stimulated fractalkine production in vascular smooth muscle cells: Evidence for mediation by NF-KB down-regulation. Br J Pharmacol 2003;138(5):950-8. 